\title{
Tipologi Ketertinggalan Wilayah pada Kabupaten Sampang
}

\author{
Fajri Majida dan Ketut Dewi Martha Erli Handayeni \\ Departemen Perencanaan Wilayah dan Kota, Fakultas Teknik Sipil, Perencanaan dan Kebumian \\ Institut Teknologi Sepuluh Nopember \\ e-mail: erli.martha@gmail.com
}

\begin{abstract}
Abstrak-Kabupaten Sampang merupakan salah satu daerah tertinggal di Provinsi Jawa Timur dan menjadi bagian prioritas penanganan. Secara lokasional, posisi Kabupaten Sampang yang strategis dekat dengan Jembatan Suramadu perlu didukung dengan upaya-upaya pemanfaatan potensi wilayah secara optimal. Strategi pengembangan potensi wilayah perlu dikembangkan sesuai dengan karakteristik ketertinggalan wilayah. Oleh karena itu, penelitian ini bertujuan untuk mengkaji tipologi ketertinggalan wilayah dengan analisa Cluster sehingga dapat memudahkan dalam menyusun rencana strategi pengembangan wilayah. Selanjutnya tipologi ketertinggalan ini dievaluasi berdasarkan tingkat aksesibilitas wilayah dengan menggunakan metode analisis Regresi Ordinal Logistik. Hasil studi menunjukkan bahwa dari 186 desa di Kabupaten Sampang, 7 desa termasuk pada tipologi ketertinggalan wilayah rendah, 140 desa termasuk pada tipologi ketertinggalan sedang dan 75 desa termasuk pada ketertinggalan tinggi. Tipologi ketertinggalan wilayah ini berasosiasi signifikan dengan tingkat aksesibilitas. Variabel jarak pusat desa menuju kecamatan memiliki pengaruh paling besar terhadap pengembangan wilayah daerah tertinggal pada Kabupaten Sampang. Sehingga semakin baik aksesibilitas wilayah maka semakin kecil tingkat ketertinggalan wilayah
\end{abstract}

Kata Kunci-Tipologi ketertinggalan wilayah, aksesibilitas wilayah, Sumber Daya Manusia, Ekonomi, Infrastruktur

\section{PENDAHULUAN}

$\mathrm{M}$ ENURUT Peraturan Presiden No.131 Tahun 2015, 122 daerah di Indonesia ditetapkan sebagai daerah dengan kategori daerah tertinggal. Defini daerah tertinggal menurut Peraturan Presiden No.78 Tahun 2014 adalah daerah kabupaten yang wilayah serta masyarakatnya kurang berkembang dibandingkan dengan wilayah lain dalam skala nasional. Pemerintah menentukan daerah tertinggal berdasarkan kebijakan keputusan menteri daerah tertinggal No.1 Tahun 2005 yaitu terdapat enam kriteria yang meliputi perekonomian masyarakat yang tergolong miskin (pertumbuhan ekonomi), kualitas sumber daya manusia, ketersediaan sarana dan prasarana, aksesibilitas, kemampuan keuangan lokal serta karakteristik daerah terutama yang berkaitan dengan daerah yang rawan bencana. Dari 122 daerah yang ditetapkan sebagai daerah tertinggal di Indonesia, Provinsi Jawa Timur memiliki lima daerah tertinggal, salah satunya adalah Kabupaten Sampang.

Salah satu misi yang dijelaskan pada peraturan Daerah Provinsi Jawa Timur tahun 2011 tentang Rencana Tata Ruang Wilayah Provinsi Jawa Timur tahun 2011-2031 adalah keseimbangan pemerataan pembangunan antar wilayah dan pertumbuhan ekonomi. Oleh karena itu pada RPJMN tahun
2014-2019 dan RPJMD Provinsi Jawa Timur tahun 2014-2019 memprioritaskan pembangunan kawasan tertinggal yang diarahkan pada wilayah selatan Jawa Timur dan Madura serta kepulauannya. Melalui Peraturan Presiden No.45 tahun 2016 diterbitkan Rencana Kerja Pemerintah Tahun 2017 dimana menetapkan 54 daerah tinggal menjadi prioritas pembangunan. Penentuan prioritas penanganan daerah tertinggal setiap tahunnya berdasarkan pertimbangan bobot Indeks Ketertinggalan yang paling rendah. Salah satu daerah tertinggal prioritas di Provinsi Jawa Timur adalah Kabupaten Sampang yang terletak pada pulau Madura.

Kabupaten Sampang adalah Pusat Kegiatan Lokal (PKL) yang berfungsi sebagai pusat pelayanan lingkup lokal yaitu skala kabupaten atau beberapa kecamatan. Dalam upaya penanganan daerah tertinggal Kabupaten Sampang, terdapat beberapa strategi yang akan dilakukan oleh pemerintah. Jika dilihat dari lokasi, Kabupaten Sampang dekat dengan Jembatan Suramadu. Hal ini menjadikan Kabupaten Sampang sebagai salah satu pusat permukiman perkotaan di Wilayah Madura dan kepulauan yang nantinya akan bersinergi dengan pusat permukiman perkotaan lain yaitu Sumenep dan Pamekasan sehingga dapat mendorong perkembangan Madura dan kepulauan secara bersama. Nyatanya Kabupaten Sampang masih memiliki keterbatasan aksesibilitas dan kualitas infratsruktur dasar berdasarkan RPJMD Kabupaten Sampang Tahun 2014-2019. Beberapa wilayah belakang/hinterland yang mempunyai keterbatasan aksesibilitas secara geografis dan administrasi ke pusat pelayanan yaitu Kecamatan Sokobanah, Kecamatan Banyuates, Kecamatan Ketapang, Kecamatan Karang Penang, Kecamatan Tambelangan dan Kecamatan Sreseh berdasarkan RTRW Kabupaten Sampang Tahun 20102029. Kecamatan Sakobanah sendiri memiliki jarak ke Ibukota Kabupaten Sampang dari Ibukota kecamatannya yang berada pada Desa Sakobanah Daya paling jauh yaitu 57 Km [1].

Wilayah tertinggal merupakan gambaran atas terjadinya kesenjangan/ketimpangan wilayah. Salah satu bentuk kesenjangan yang terjadi adalah kesenjangan pendapatan dan infrastruktur (Rustiadi dkk). Salah satu penyebab keterbelakangan wilayah pedesaan adalah terjebak pada spesialisasi satu komoditas pertanian atau sumerbdaya alam untuk melayani perkotaan [2]. Faktor ketertinggalan wilayah antara lain faktor alam, sosial dan kebijakan [3]. Menurut Muta'ali (2014), kesenjangan adalah bentuk ketidakseimbangan [4]. Kebijakan pembangunan dan pengembangan wilayah juga telah terjadi pergeseran paradigma dari konsep pertumbuhan, pemerataan, keberlanjutan hingga keberimbangan. Pembangunan berimbang diwujudkan dari 
penguatan keterkaitan dan interaksi-interaksi antar wilayah. Menurut Rustiadi dkk (2009), pemerintah dapat mempengaruhi bentuk-bentuk maupun magnitude (volume) aliran-aliran dan keterkaitan melalui berbagai intervensi kebijakan [5]. Salah satunya adalah kebijakan pembangunan infrastruktur dasar perdesaan seperti misalnya pembangunan jalan/sistem transportasi. Kebijakan ini mempengaruhi aksesibilitas untuk pengembangan wilayah tertinggal. Menurut Adisasmita (2011), jika transportasi dianggap dan ditempatkan pada posisi yang strategis yaitu sebagai urat nadi penggerak dinamika pembangunan daerah dan pertumbuhan wilayah, arus pergerakan lalu lintas antar wilayah dan dalam lingkup wilayah meliputi kegiatan perdagangan, perekonomian mobilitas penduduk, maka pembangunan akan lebih baik [6]. Aksesibilitas memiliki peran penting bagi pengembangan suatu wilayah.

Kriteria aksesibilitas merupakan salah satu kriteria daerah tertinggal menurut standar yang telah ditetapkan oleh Peraturan Menteri Desa, Pembangunan Daerah Tertinggal dan Transmigrasi No.3 Tahun 2016 tentang Petunjuk Teknis Penentuan Indikator daerah tertinggal secara Nasional. Kriteria aksesibilitas ini berkaitan dengan rata-rata jarak ke ibukota Kabupaten.

Dalam upaya mengentaskan ketertinggalan wilayah, pemerintah melakukan berbagai strategi. Metode yang digunakan dalam menganalisa pembangunan dalam daerah tertinggal adalah Indeks Desa Membangun (IDM) dan Indeks Pembangunan Desa (IPD). IDM dan IPD memiliki metode dengan cara mengkelompokkan desa-desa tertinggal berdasarkan karakteristik pengembangan desa berstandar nasional untuk mengetahui status perkembangan setiap desanya, sehingga memudahkan pemerintah untuk membuat kebijakan dan strategi yang tepat dalam mencapai tujuan pengentasan ketertinggalan wilayah.

Penelitian ini bertujuan untuk mengkaji tipologi ketertinggalan wilayah di Kabupaten Sampang dengan cara mengkelompokkan desa-desa menjadi beberapa kelompok berdasarkan karakteristik pengembangan wilayahnya. Selanjutnya, tipologi ini dievaluasi keterkaitannya dengan tingkat aksesibilitas wilayah. Manfaat dari penelitian ini adalah memberikan perspektif pengembangan wilayah dalam kerangka sistem transportasi sehingga dapat dikembangkan rekomendasi bagi kebijakan pengembangan wilayah tertinggal dari sisi aksesibilitas.

\section{METODE PENELITIAN}

\section{A. Pendekatan dan Jenis Penelitian}

Pendekatan yang digunakan dalam penelitian ini adalah pendekatan positivistik yaitu penelitian yang melihat teori-teori yang bersangkutan dengan penelitian kemudian dibandingkan dengan fakta yang terdapat dilapangan. Melalui data-data yang beririsan dengan daerah tertinggal untuk menganalisa tipologi ketertinggalan setiap desa yang terdapat di Kabupaten Sampang. Jenis penelitian ini adalah penelitian kuantitatif. selain itu juga menggunakan analisa deskriptif untuk mendukung dalam menjelaskan secara sistematis, akurat dan faktual terkait penelitian.

\section{B. Variabel Penelitian}

Terdapat 12 variabel pada penelitian ini yang terbagi menjadi 4 indikator, yakni indikator ketertinggalan wilayah pada Kabupaten Sampang dapat dilihat pada Tabel 1. Tipologi ketertinggalan wilayah dibangun dari tiga indikator, yaitu sumber daya manusia, ekonomi dan infrastruktur. Selanjutnya, evaluasi terhadap aksesibilitas wilayah dengan tipologi ketertinggalan wilayah menggunakan lima variabel yang termasuk indikator aksesibilitas.

Tabel 1.

Indikator dan Variabel Penelitian

\begin{tabular}{cl}
\hline \hline \multicolumn{1}{c}{ Indikator } & \multicolumn{1}{c}{ Variabel } \\
\hline Sumber Daya Manusia & Tingkat Pendidikan \\
\hline Ekonomi & Pendapatan per Kapita \\
\hline Infrastruktur & Fasilitas Pendidikan \\
\cline { 2 - 2 } & Fasilitas Kesehatan \\
\cline { 2 - 2 } & Fasilitas Perekonomian \\
\cline { 2 - 2 } & Jaringan Air Bersih \\
\hline Aksesibilitas & Jaringan Listrik \\
\hline & Jarak pusat desa menuju kecamatan \\
\hline & Total pusat desa menuju kabupaten jalan per luas desa \\
\hline \hline & Waktu tempuh menuju kecamatan \\
\hline
\end{tabular}

\section{Metode Pengumpulan Data dan Metode Analisis}

Populasi pada penelitian ini adalah 186 desa yang terdapat di 14 kecamatan di Kabupaten Sampang. Pengumpulan data dilakukan dengan teknik survey sekunder. Teknik survey ini dilakukan dengan memperoleh data-data melalui sumber Badan Pusat Statistik (BPS) Kabupaten Sampang maupun lembaga/instansi terkait di Kabupaten Sampang seperti Dinas Pendidikan, Dinas Kesehatan, Dinas Pekerjaan Umum dan Cipta Karya, Dinas Perhubungan dan lain-lain.

Teknik analisis yang digunakan untuk menyusun tipologi ketertinggalan wilayah adalam metode analisis Cluster dan teknik Skoring. Analisis Cluster pada prinsipnya digunakan untuk membentuk kelompok atau kluster atas dasar kemiripan karakteristik diantara anggota kelompok [7]. Analisis Cluster pada studi ini menggunakan metode K-Means bertujuan membentuk kelompok-kelompok desa di Kabupaten Sampang berdasarkan tiga indikator yaitu sumber daya manusia, ekonomi dan infrastruktur. Hasil pembentukan cluster diberikan skor tinggi, sedang, rendah. Untuk cluster berdasarkan indikator sumber daya manusia, infrastruktur dan ekonomi yang berada pada karakteristik tinggi mempunyai nilai 3, karakteristik sedang mempunyai nilai 2 dan karakteristik rendah mempunyai nilai 1. Selanjutnya hasil skoring pada ketiga indikator dijumlahkan untuk memperoleh tipologi ketertinggalan wilayah. Wilayah dengan total skor sama dengan 3 termasuk kategori ketertinggalan tinggi, total skor antara 4-6 termasuk ketertinggalan sedang, dan total skor antara 7-9 adalah tipe ketertinggalan rendah.

Hasil tipologi ketertinggalan wilayah dievaluasi berdasarkan tingkat aksesibilitas wilayah setiap desa. Evaluasi ini menggunakan teknik analisis Regresi Ordinal Logistik. Regresi ordinal logistik merupakan teknik regresi dimana respon/variabel dependen berupa variabel kategorial yang berjenjang/bertingkat (ordered categories) [8]. Pada studi ini, variabel dependen ditetapkan adalah kategori ketertinggalan wilayah dan variabel independen adalah lima variabel yang 
merupakan indikator aksesibilitas. Beberapa uji statistik digunakan untuk menguji kecocokan model (Goodness of Fit) dan uji parameter model. Pengolahan data dengan analisis regresi ordinal logistic ini menggunakan perangkat lunak SPSS 24.

\section{HASIL DAN DISKUSI}

\section{A. Tipologi Ketertinggalan Wilayah berdasarkan Indikator Ekonomi}

Input pada analisa ini adalah pendapatan per kapita penduduk Kabupaten Sampang. Pendapatan per kapita adalah rata-rata pendapatan per bulan yang didapatkan oleh penduduk setiap desa/kelurahan. Analisis ini bertujuan untuk mengkelompokkan desa-desa kedalam beberapa kelompok berdasarkan karakteristik ekonominya, sehingga desa-desa yang memiliki karakteristik ekonomi yang hampir sama akan menjadi satu kelompok. Adapun hasilnya sebagai berikut:
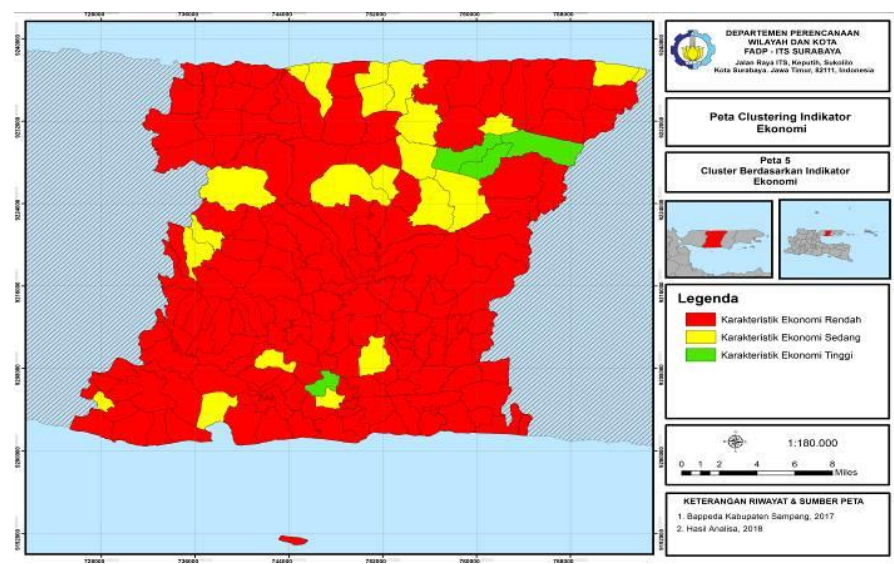

Gambar 1. Peta Tipologi Ketertinggalan Wilayah berdasarkan Ekonomi Tabel 2.

Tipologi Ketertinggalan Wilayah berdasarkan Ekonomi

\begin{tabular}{ccc}
\hline \hline Kelompok & Jumlah Desa & Rata-Rata Pendapatan \\
\hline $\begin{array}{c}\text { Karakteristik } \\
\text { Ekonomi Sedang }\end{array}$ & 22 & Rp. 2.634.068 \\
\hline $\begin{array}{c}\text { Karakteristik } \\
\text { Ekonomi Rendah }\end{array}$ & 160 & Rp. 889.980 \\
\hline $\begin{array}{c}\text { Karakteristik } \\
\text { Ekonomi Maju }\end{array}$ & 4 & Rp. 8.975.000 \\
\hline \hline
\end{tabular}

Dari tabel dan gambar diatas dapat dilihat bahwa mayoritas Kabupaten Sampang memiliki karakteristik ekonomi yang rendah yaitu 160 desa dengan rata-rata pendapatan Rp.889.9880,00.

\section{B. Tipologi Ketertinggalan Wilayah berdasarkan Sumber Daya Manusia}

Input pada analisa ini tingkat pendidikan penduduk Kabupaten Sampang. Definisi operasional tingkat pendidikan adalah jumlah penduduk yang berpendidikan akhir SMP atau lebih dari SMP sederajat disetiap desa atau kelurahan di Kabupaten Sampang. Analisis ini bertujuan untuk mengkelompokkan desa-desa kedalam beberapa kelompok berdasarkan karakteristik sumber daya manusianya, sehingga desa-desa yang memiliki karakteristik sumber daya manusia yang hampir sama akan menjadi satu kelompok. Adapun hasilnya sebagai berikut:
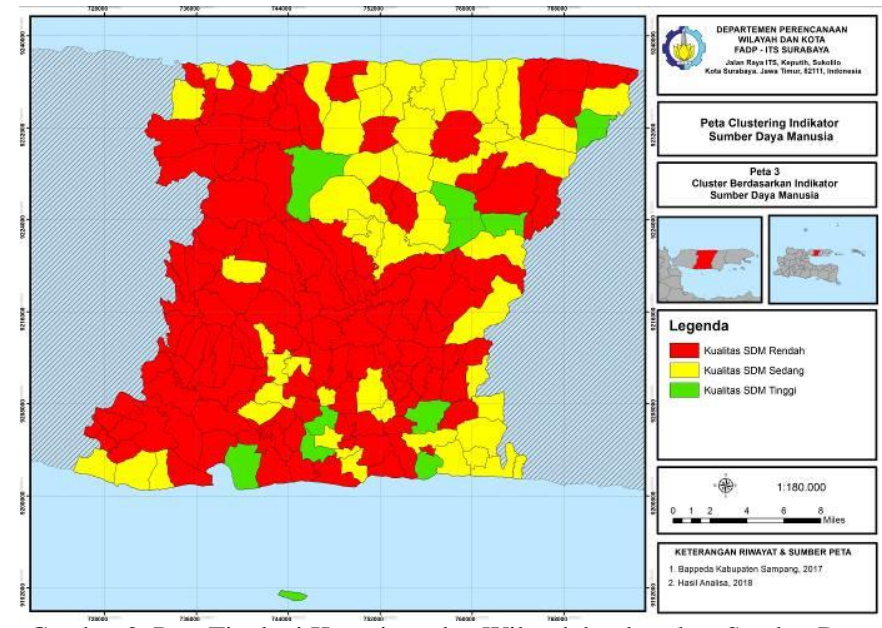

Gambar 2. Peta Tipologi Ketertinggalan Wilayah berdasarkan Sumber Daya Manusia

Tabel 3.

Tipologi Ketertinggalan Wilayah berdasarkan Sumber Daya Manusia

\begin{tabular}{ccc}
\hline \hline Kelompok & Jumlah Desa & Rata-Rata SDM (jiwa) \\
\hline Kualitas SDM Tinggi & 10 & 3.502 \\
\hline Kualitas SDM Rendah & 125 & 438 \\
\hline Kualitas SDM Sedang & 51 & 1.431 \\
\hline \hline
\end{tabular}

Dari tabel dan gambar diatas dapat dilihat bahwa mayoritas Kabupaten Sampang memiliki kualitas Sumber Daya Manusia yang rendah yaitu 125 desa dengan rata-rata penduduk yang memiliki tingkat pendidikan SMP atau lebih dari SMP adalah 438 jiwa.

\section{Tipologi Ketertinggalan Wilayah berdasarkan Infrastruktur}

Input pada analisa ini fasilitas kesehatan, fasilitas pendidikan, fasilitas perekonomian, jaringan air bersih dan jaringan listrik. Definisi operasional dari fasilitas kesehatan, fasilitas pendidikan dan fasilitas perekonomian adalah jumlah ketersediaan dari maisngmasing fasilitas. Sedangkan untuk jaringan air bersih dan jaringan listrik adalah jumlahpersentase rumah tangga yang terlayani jaringan PDAM dan PLN Analisis ini bertujuan untuk mengkelompokkan desa-desa berdasarkan ketersediaan infrastrukturnya, sehingga desa-desa yang memiliki ketersediaan infrastruktur yang hampir sama akan menjadi satu kelompok. Adapun hasilnya sebagai berikut:

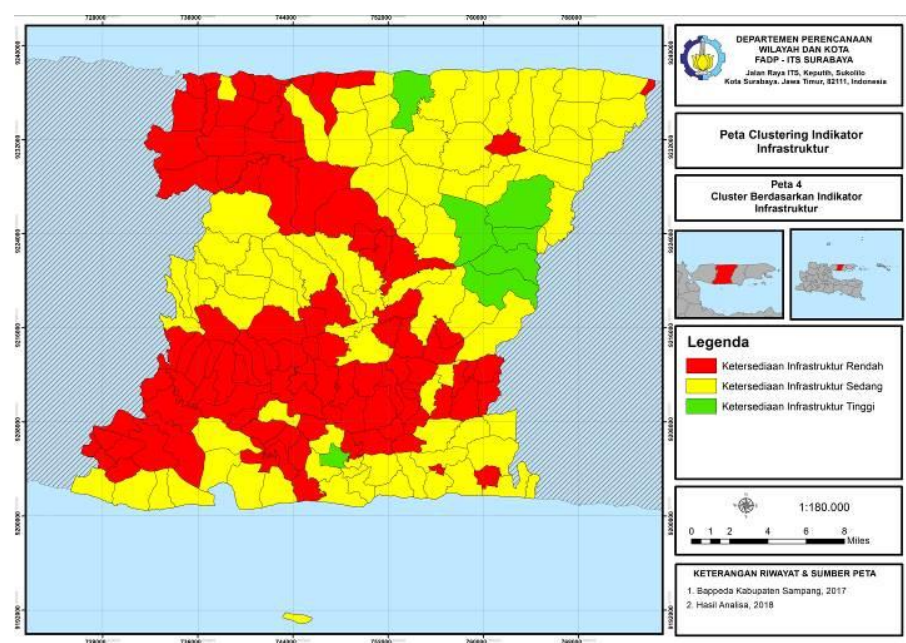

Gambar 3. Peta Tipologi Ketertinggalan Wilayah berdasarkan Infrastruktur 
Tabel 4.

Tipologi Ketertinggalan Wilayah berdasarkan Infrastruktur

\begin{tabular}{ccl}
\hline \hline Kelompok & Jumlah Desa & \multicolumn{1}{c}{ Keterangan } \\
\hline Ketersediaan & 82 & - Fasilitas Kesehatan : 5-17 \\
Infrastruktur Sedang & & - Fasilitas Ekonomi : 18-295 \\
& & - Fasilitas Pendidikan : 6-32 \\
& - Pelayanan PDAM : 0-81,03\% \\
& & - Pelayanan PLN : 37,31-100 \\
\hline Ketersediaan & 7 & - Fasilitas Kesehatan : 7-19 \\
Infrastruktur Maju & & - Fasilitas Ekonomi : 179-496 \\
& & - Fasilitas Pendidikan : 27-76 \\
& & - Pelayanan PDAM : 0-77,66\% \\
Ketersediaan & 97 & - Fasilitas Kesehatan : $1-9$ \\
Infrastruktur Rendah & & - Fasilitas Ekonomi : 4-179 \\
& & - Fasilitas Pendidikan : 2-21 \\
& & Pelayanan PDAM : $0-100 \%$ \\
\hline \hline
\end{tabular}

Dari tabel dan gambar diatas dapat dilihat bahwa mayoritas Kabupaten Sampang memiliki ketersediaan infrastruktur yang rendah yaitu 97 desa dengan fasilitas kesehatan sekitar 1-9 unit fasilitas ekonomi 4-197 unit, fasilitas pendidikan sekitar 2-21 unit, pelayanan air bersih PDAM untuk rumah tangga yang hampir $100 \%$ dan pelayanan listrik PLN untuk rumah tangga sekitar 5, 19- 100\%.

\section{Pemberian Nilai Skoring Ketertinggalan Wilayah}

Berdasarkan hasil masing-masing kluster berdasarkan indikator sumber daya manusia, infrastruktur dan ekonomi sebelumnya, kemudian dilakukan skoring untuk masingmasing desa berdasarkan hasil kluster yang diperoleh. Skor dari masing-masing indikator mempunyai skor yang sama, skor yang berbeda terdapat pada karakteristik masing-masing indikator. Berikut adalah skor untuk masing-masing karakteristik

Tabel 5 .

Nilai Skor dari Cluster berdasarkan Indikator Ekonomi, Infrastruktur dan SDM

\begin{tabular}{cc}
\hline \hline Cluster berdasarkan Ekonomi, Inrastruktur dan SDM & Nilai Skor \\
\hline Tinggi & 3 \\
\hline Sedang & 2 \\
\hline Rendah & 1 \\
\hline \hline
\end{tabular}

Setelah mendapatkan skor dari masing-masing desa berdasarkan cluster sumber daya manusia, infrastruktur dan ekonomi kemudian dilanjutkan dengan mentotal nilai skor agar mendapatkan satu nilai skor terakhir untuk dijadikan nilai dalam menentukan tipologi ketertinggalan wilayah. Berikut adalah kriteria skor dalam menentukan tipologi ketertinggalan wilayah.

Tabel 6.

Kriteria Nilai Skor Tingkat Ketertinggalan Wilayah

\begin{tabular}{cc}
\hline \hline Kriteria Nilai Skor & Tipologi Wilayah Tertinggal \\
\hline $7-9$ & Tingkat Ketertinggalan Rendah \\
\hline $4-6$ & Tingkat Ketertinggalan Sedang \\
\hline 3 & Tingkat Ketaertinggalan Tinggi \\
\hline \hline
\end{tabular}

Dari tabel diatas dapat dlihat bahwa desa yang mempunyai total nilai skor 7-9 termasuk pada tipologi desa dengan tingkat ketertinggalan wilayah rendah, desa yang mempunyai total nilai skor 4-6 termasuk pada tipologi desa dengan tingkat ketertinggalan wilayah sedang dan desa yang mempunyai total nilai skor 3 mempunyai tingkat ketertinggalan tinggi.

\section{E. Tipologi Ketertinggalan Wilayah Kabupaten Sampang}

Setelah mendapatkan masing-masing tipologi pada tingkat ketertinggalan wilayah pada daerah tertinggal, maka dilakukan interpretasi karakteristik pada masing-masing tingkat ketertinggalan wilayah yang didapatkan berdasarkan analisa cluster dan skoring sebelumnya.

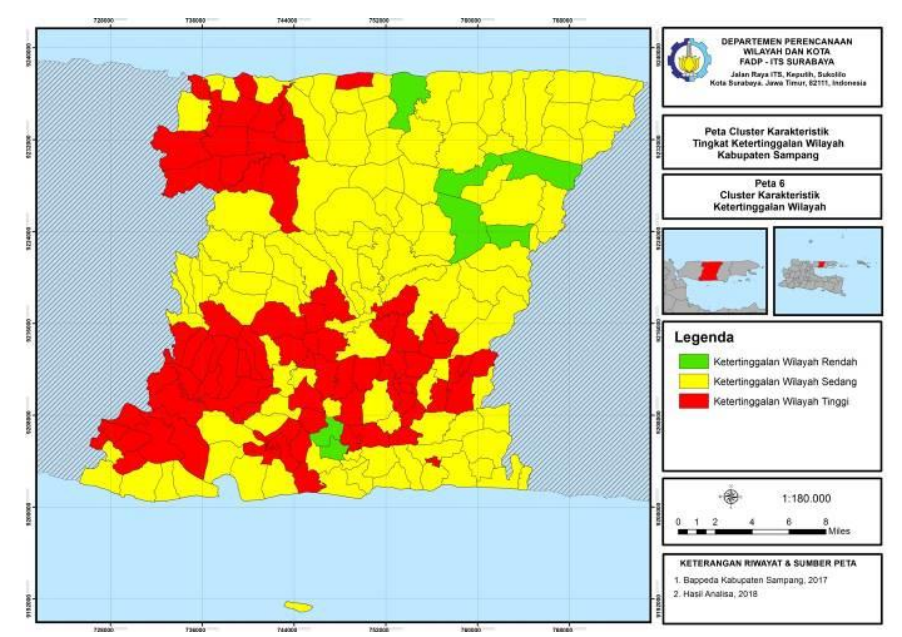

Gambar 4. Peta Tipologi Ketertinggalan Wilayah Kabupaten Sampang Tabel 7.

Tipologi Ketertinggalan Wilayah pada Kabupaten Sampang

\begin{tabular}{|c|c|c|c|}
\hline Tipe & $\begin{array}{c}\text { Tingkat } \\
\text { Ketertinggala } \\
\text { WIlayah }\end{array}$ & $\begin{array}{c}\text { Jumlah } \\
\text { Desa }\end{array}$ & Deskripsi \\
\hline $\begin{array}{c}\text { Tipe } \\
\text { I }\end{array}$ & $\begin{array}{l}\text { Desa dengan } \\
\text { tingkat } \\
\text { ketertinggalan } \\
\text { wilayah rendah }\end{array}$ & 7 & $\begin{array}{c}\text { Desa-desa pada tipe ini } \\
\text { mayoritas memiliki } \\
\text { karakteristik ekonomi sedang, } \\
\text { ketersediaan infrastruktur } \\
\text { tinggi dan kualitas SDM } \\
\text { sedang. }\end{array}$ \\
\hline
\end{tabular}

\begin{tabular}{|c|c|c|c|}
\hline $\begin{array}{c}\text { Tipe } \\
\text { II }\end{array}$ & $\begin{array}{l}\text { Desa dengan } \\
\text { tingkat } \\
\text { ketertinggalan } \\
\text { wilayah sedang }\end{array}$ & 104 & $\begin{array}{c}\text { Desadesa pada tipe ini } \\
\text { mayoritas memiliki } \\
\text { karakteristik ekonomi rendah, } \\
\text { ketersediaan infrastruktur } \\
\text { sedang dan kualitas SDM } \\
\text { rendah }\end{array}$ \\
\hline
\end{tabular}

\begin{tabular}{|c|c|c|c|}
\hline $\begin{array}{c}\text { Tipe } \\
\text { III }\end{array}$ & $\begin{array}{l}\text { Desa dengan } \\
\text { tingkat } \\
\text { ketertinggalan } \\
\text { wilayah tinggi }\end{array}$ & 75 & $\begin{array}{l}\text { Desa-Desa pada tipe ini } \\
\text { memiliki karakteristik } \\
\text { Ekonomi, Ketersediaan } \\
\text { Infrastruktur dan kualita } \\
\text { SDM semuanya rendah }\end{array}$ \\
\hline
\end{tabular}

Dari tabel diatas dapat dilihat bahwa mayoritas desa -desa pada Kabupaten Sampang termasuk pada desa tipe II yaitu desa dengan tingkat ketertinggalan wilayah sedang yaitu mayoritas memiliki karakteristik ekonomi rendah, ketersediaan infratsruktur sedang dan kualitas sumber daya manusia rendah.

F. Evaluasi Aksesibilitas Wilayah berdasarkan Tipologi Ketertinggalan Wilayah

Pada studi ini, aksesibilitas wilayah ditinjau dari lima variabel yaitu jarak desa ke kecamatan, jarak desa ke kabupaten, panjang jalan per luas desa, waktu tempuh menuju kecamatan dan waktu tempuh menuju kabupaten. Berdasarkan variabel jarak desa menuju kecamatan, sebagian besar desa 
memiliki aksesibilitas tinggi, seperti pada gambar 5. Sebagian kecil desa-desa memiliki aksesibilitas rendah, seperti pada gambar 6. Artinya, sebagian besar pusat-pusat desa mudah menjangkau pusat kecamatan. Namun, berbeda dengan jarak desa menuju pusat ibu kota kabupaten. Sebagian besar desa memiliki aksesibilitas sedang jika diukur dari jarak menuju pusat ibu kota kabupaten, seperti yang terlihat pada gambar 7 . Setiap pusat desa cukup dapat menjangkau pusat ibu kota kabupaten, kecuali bagi desa-desa di wilayah selatan Kabupaten Sampang memiliki aksesibilitas tinggi menuju pusat ibu kota kabupaten, seperti yang terlihat pada gambar 8.

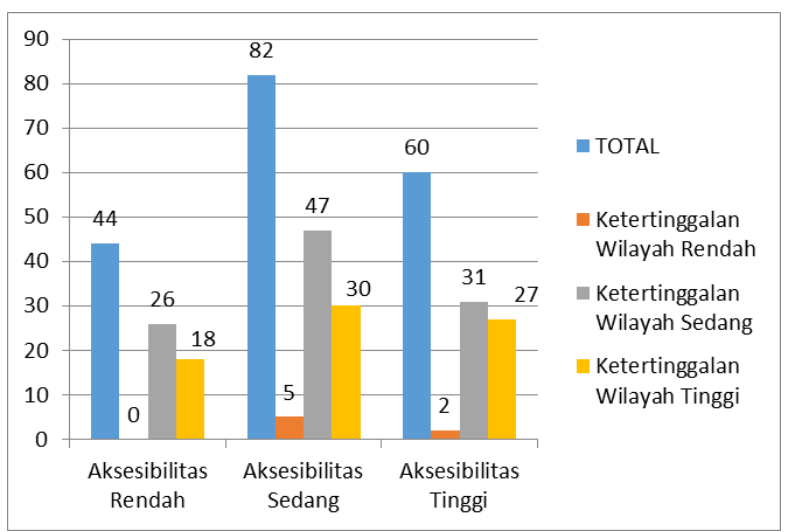

Gambar 5. Jumlah Kluster Wilayah Tertinggal berdasarkan Ukuran Jarak Desa menuju Pusat Kecamatan

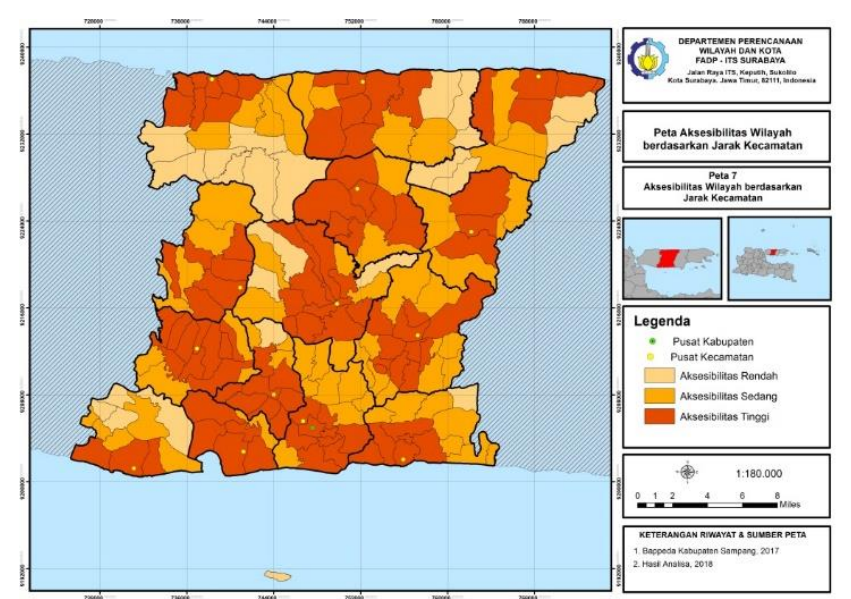

Gambar 6. Sebaran Tingkat Aksesibilitas menurut Ukuran Jarak Desa menuju Pusat Kecamatan

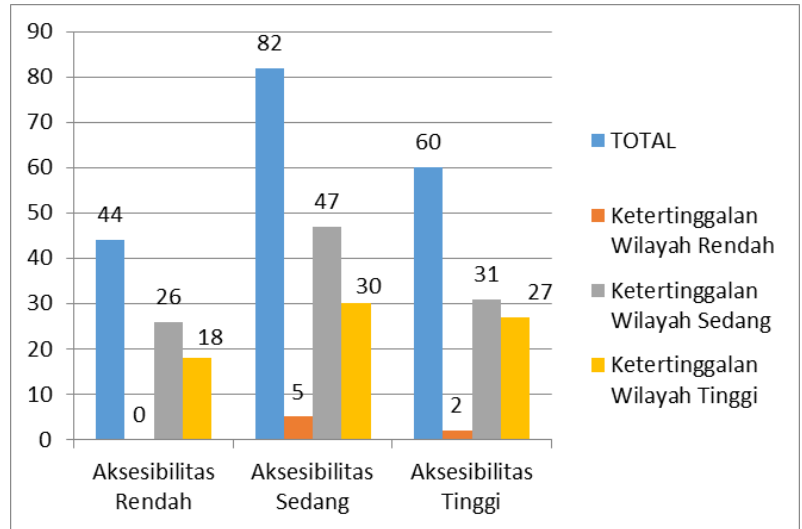

Gambar 7. Jumlah Kluster Wilayah Tertinggal berdasarkan Ukuran Jarak Desa menuju Pusat Ibu Kota Kabupaten

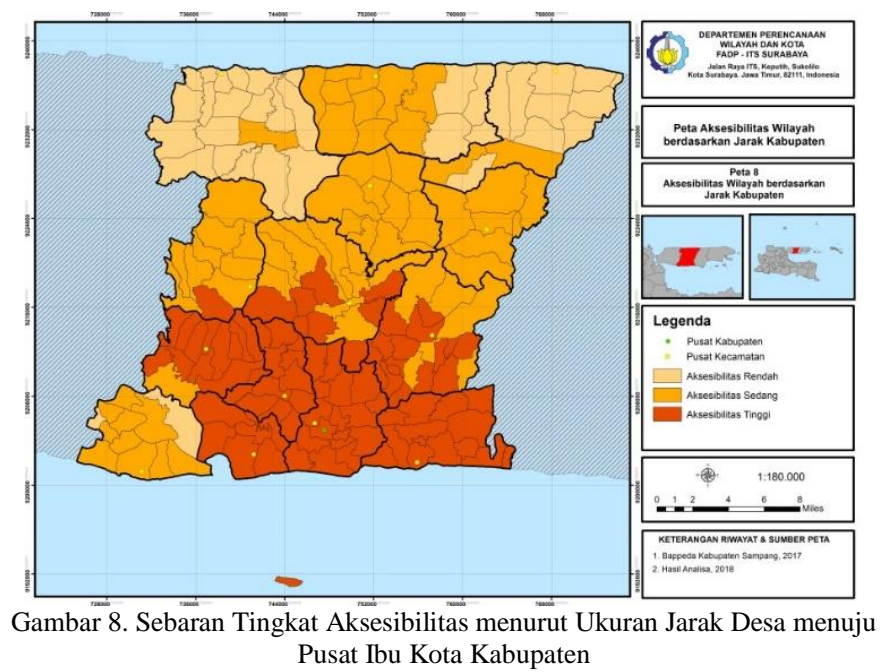

Berdasarkan variabel panjang jalan per luas wilayah desa, sebagian besar desa memiliki kategori aksesibilitas rendah, seperti yang terlihat pada gambar 9. Hanya sebagian kecil desa yang memiliki aksesibilitas tinggi dari segi panjang jalan per luas wilayah desa, seperti pada gambar 10. Artinya, ketersediaan infrastruktur jalan di seluruh desa di Kabupaten Sampang masih rendah untuk mendukung mobilitas penduduk, serta mempengaruhi tingkat ketertinggalan wilayahnya.

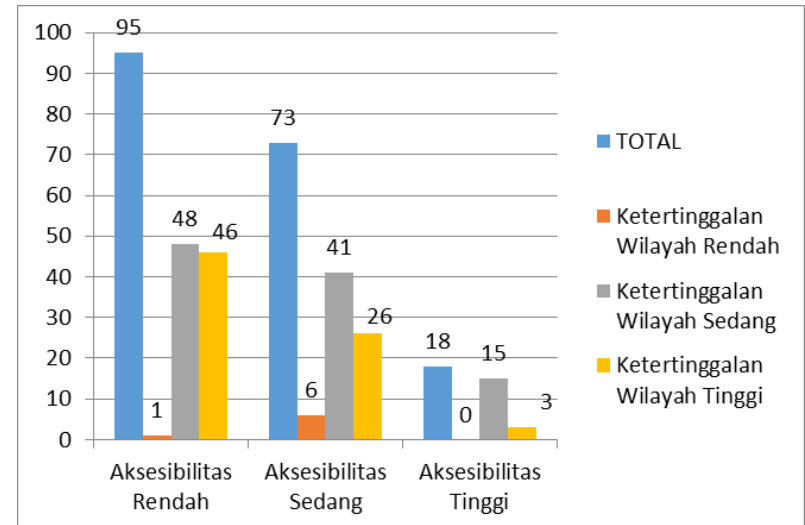

Gambar 9. Jumlah Kluster Wilayah Tertinggal berdasarkan Ukuran Panjang Jalan per Luas Desa

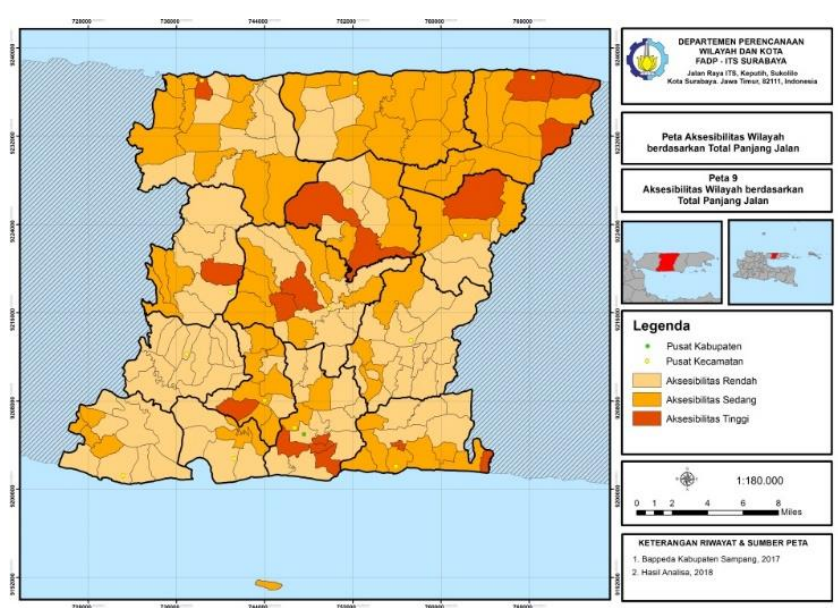

Gambar 10. Sebaran Tingkat Aksesibilitas menurut Ukuran Panjang Jalan per Luas Desa 
Berdasarkan variabel waktu tempuh, hampir sebagian besar desa di Kabupaten Sampang memiliki aksesibilitas sedang jika diukur dari waktu tempuh menuju pusat kecamatan maupun pusat ibu kota kabupaten. Pada gambar 11 menunjukkan jumlah kluster wilayah tertinggal berdasarkan ukuran waktu tempuh menuju kecamatan. Selanjutnya pada gambar 12 menjelaskan pola sebaran tingkat aksesibilitas desa menuju kecamatan diukur dari waktu tempuh.

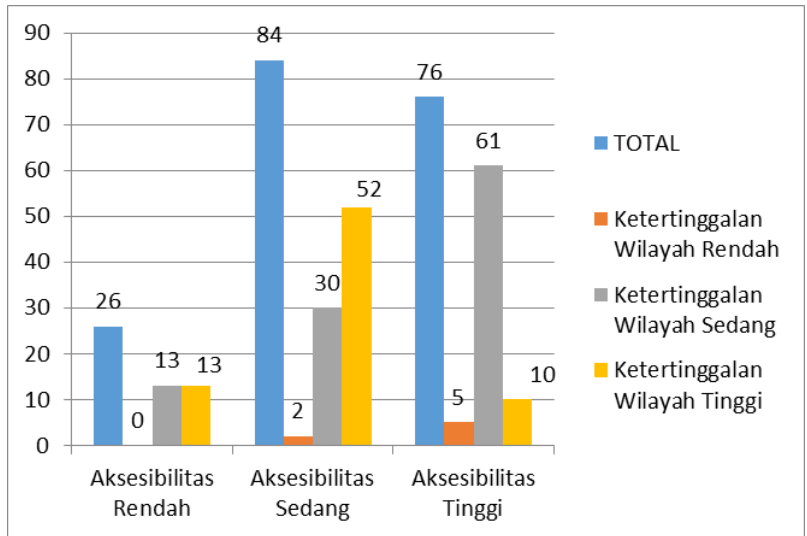

Gambar 11. Jumlah Kluster Wilayah Tertinggal berdasarkan Ukuran Waktu Tempuh dari Desa menuju Pusat Kecamatan

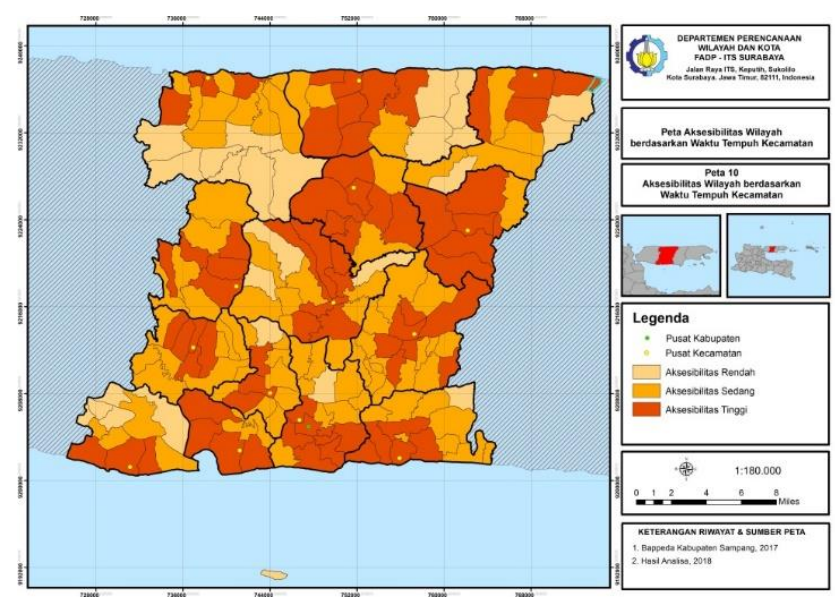

Gambar 12. Sebaran Tingkat Aksesibilitas menurut Ukuran Waktu Tempuh dari Desa menuju Pusat Kecamatan

Berbeda dengan waktu tempuh menuju pusat ibu kota kabupaten, pola sebaran desa yang memiliki aksesibilitas tinggi cenderung terlihat pada desa-desa di bagian wilayah selatan Kabupaten Sampang, seperti yang terlihat pada gambar 14 . Pada gambar 13 menunjukkan jumlah wilayah tertinggal dengan kategori ketertinggal tinggi memiliki aksesibilitas kategori sedang dibandingkan dengan wilayah dengan kategori ketertinggalan rendah. Gambaran awal mengenai pola sebaran aksesibilitas dari kelima variabel berdasarkan kategori ketertinggaln wilayah menunjukkan adanya pola hubungan antara aksesibilitas dengan tipologi ketertinggalan wilayah.

Berdasarkan analisis Regresi Ordinal Logistik, variabel respon merupakan variabel dependen yang terdiri dari tiga kategori ketertingalan wilayah. Selanjutnya, variabel predictor adalah variabel independen yang terdiri dari lima variabel penjelas aksesibilitas wilayah. Pada tabel 8,9 dan 10 menunujukkan hasil pengujuian statistik terhadap model yang terbangun.

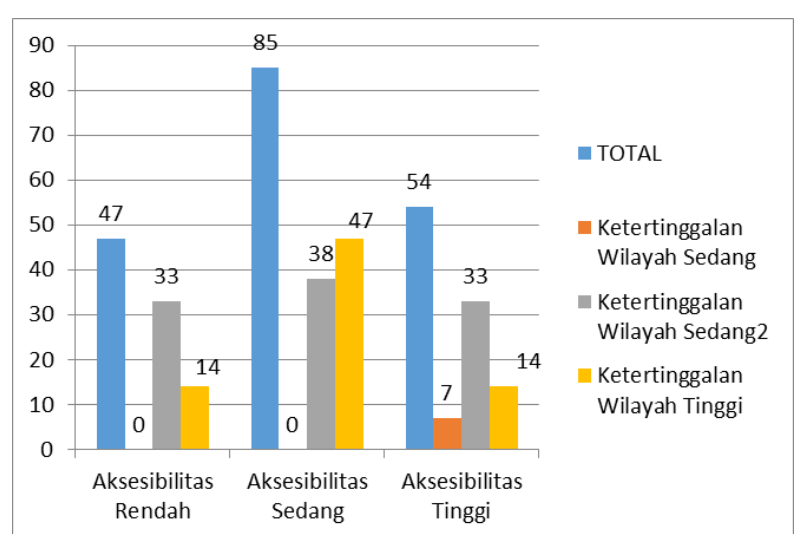

Gambar 13. Jumlah Kluster Wilayah Tertinggal berdasarkan Ukuran Waktu Tempuh dari Desa menuju Pusat Ibu Kota Kabupaten

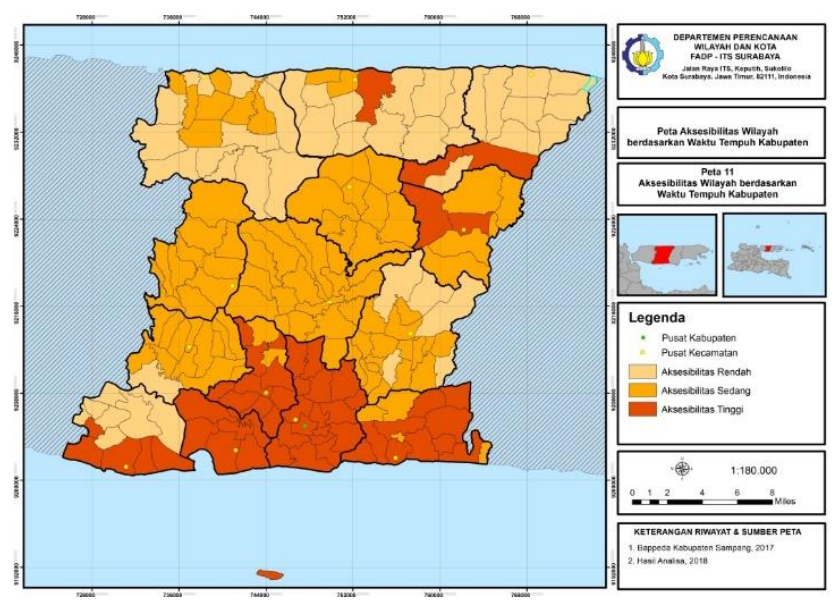

Gambar 14. Jumlah Kluster Wilayah Tertinggal berdasarkan Ukuran Waktu Tempuh dari Desa menuju Pusat Ibu Kota Kabupaten

Pada tabel 8 dijelaskan mengenai hasil pengujian kesesuaian model dengan data (Goodness of Fit) yang menunjukkan nilai Pearson sebesar 206,442 dengan signifikansi 1 dan Deviance sebesar 133,680 dengan signifikansi 1. Artinya, nilai signifikansi lebih dari 0,1 menyatakan bahwa $\mathrm{H} 0$ diterima dan H1 ditolak, sehingga model sesuai dengan data empiris atau model logit layak digunakan.

Tabel 8.

Uji Goodness of Fit

\begin{tabular}{ccc}
\hline \hline & Chi-Square & Sig \\
\hline Pearson & 206,442 & 1,000 \\
\hline Deviance & 133,680 & 1,000 \\
\hline \hline
\end{tabular}

Selanjunya, pada tabel 9 menunjukkan hasil pengujian serentak (Model Fitting Information) yang menjelaskan apakah terdapat variabel yang signifikan pada model. Nilai final (-2 Log Likehood) tanpa memasukkan variabel prediktor atau independen kedalam model adalah 303,078 dan nilai final (-2 Log Likehood) dengan memasukkan variabel prediktor atau independen kedalam model sebesar 133,680 dengan nilai ChiSquare 169,399. Taraf signifikansi yang digunakan adalah 0,1 sedangkan nilai signifikansi pada tabel 9 menunujukkan sebesar 0,0 . Artinya, kesimpulan hipotesa adalah bahwa H0 ditolak dan H1 diterima yang berarti minimal terdapat satu variabel yang signifikan dalam model. 
Tabel 9.

Uji Serentak Model Regresi Ordinal Logistik

\begin{tabular}{cccc}
\hline \hline Model & $\begin{array}{c}\mathbf{- 2} \text { Log } \\
\text { Likehood }\end{array}$ & Chi-Square & Sig \\
\hline Intercept Only & 303,078 & & \\
\hline Final & 133,680 & 169,399 & $\left.0,000^{*}\right)$ \\
\hline \hline *) signifikan dengan taraf $10 \%$ & &
\end{tabular}

Terakhir, pengujian parameter pembentuk model dilihat melalui uji parsial pada regresi logistik, seperti pada tabel 10 . Pada tabel 10 menunjukkan bahwa terdapat tiga variabel, yaitu X1 adalah jarak menuju pusat kecamatan; X3 adalah panjang jalan per luas desa; dan X4 adalah waktu tempuh menuju pusat kecamatan memiliki nilai taraf signifikansi kurang dari 0,1 . Artinya, ketiga variabel ini memiliki pengaruh yang signifikan terhadap tingkat ketertinggalan wilayah di Kabupaten Sampang. Sementara, dua variabel lainnya yaitu X2 (jarak pusat desa menuju kabupaten) dan X5 (waktu tempuh menuju pusat ibu kota kabupaten) memiliki nilai tarat signifikansi $>0,1$, artinya kedua variabel ini tidak berpengaruh signifikan terhadap tingkat ketertinggalan wilayah.

Tabel 10

Uji Parsial Model Regresi Ordinal Logistik

\begin{tabular}{ccccc}
\hline \hline Variabel & Koefisien & Wald & Signifikansi & Odd Ratio \\
\hline Konstanta (1) & $-5,045$ & 25,096 & $0,000^{*}$ & \\
\hline Konstanta (2) & 2,359 & 6,033 & $0,014^{*}$ & \\
\hline X1 & 2,057 & 49,766 & $0,000^{*}$ & 7,822467 \\
\hline X2 & 0,030 & 2,228 & 0,135 & 1,030455 \\
\hline X3 & $-0,254$ & 54,939 & $0,000^{*}$ & 0,775692 \\
\hline X4 & 0,361 & 6,082 & $0,014^{*}$ & 1,434763 \\
\hline X5 & $-0,015$ & 2,189 & 0,139 & 0,985112 \\
\hline \hline
\end{tabular}

*) signifikan dengan taraf $10 \%$

Berdasarkan hasil pengujian parameter model regresi ordinal logistik, maka dapat dijelaskan bahwa nilai koefisien yang memiliki tanda negatif (-) memiliki pengaruh menurunkan peluang pada tingkat ketertinggalan wilayah tinggi sedangkan tanda positif (+) memiliki pengaruh menaikkan peluang pada tingkat ketertinggalan wilayah tinggi. Berdasarkan nilai koefisien menunjukkan bahwa variabel X1 (jarak menuju pusat kecamatan) memiliki pengaruh paling tinggi dibandingkan dua variabel lainnya X3 dan X4. Nilai Odd Ratio menunjukkan bahwa:

1) setiap penambahan 1 satuan jarak desa menuju pusat kecamatan (X1) maka akan meningkatkan peluang desa tersebut untuk masuk pada kategori tingkat ketertinggalan tinggi sebesar 7,82 kali dibandingkan masuk ke kategori tingkat ketertinggalan sedang dan rendah. Artinya semakin panjang jarak desa menuju pusat kecamatan, maka akan semakin rendah aksesibilitas dan semakin tertinggal wilayah desa tersebut.

2) setiap penambahan 1 satuan panjang jalan per luas desa maka akan menurunkan peluang desa tersebut untuk masuk pada kategori tingkat ketertinggalan tinggi sebesar 0,78 kali dibandingkan masuk ke kategori tingkat ketertinggalan sedang dan rendah. Artinya semakin tinggi panjang jalan per luas desa, maka akan semakin tinggi aksesibilitas dan tingkat ketertinggalan wilayah desa tersebut akan semakin rendah.
3) setiap penambahan 1 satuan waktu tempuh menuju pusat kecamatan (X4) maka akan menaikkan peluang desa tersebut untuk masuk pada kategori tingkat ketertinggalan tinggi sebesar 0,99 kali dibandingkan masuk ke kategori tingkat ketertinggalan sedang dan rendah. Artinya semakin besar waktu yang dibutuhkan untuk menuju pusat kecamatan, maka akan semakin rendah aksesibilitas dan semakin tertinggal wilayah desa tersebut.

Hasil analisis regresi ordinal logistik menunjukkan bahwa aksesibilitas wilayah menentukan tipologi ketertinggalan wilayah di Kabupaten Sampang. Tujuh desa dengan tipe ketertinggalan wilayah rendah menunjukkan aksesibilitas tinggi dengan jarak menuju pusat kecamatan antara $0,1-2 \mathrm{~km}$, panjang jalan per luas desa antara $2,8-5,4 \mathrm{~km} / \mathrm{Ha}$, dan waktu tempuh menuju pusat kecamatan sekitar $0,1-0,5$ jam. Ketujuh desa tersebut adalah Desa Gunung Sekar, Desa Ketapang Daya, Desa Tobaik Barat, Desa Tobaik Timur, Desa Tanggumong, Desa Gunung Kesan, dan Desa Karang Penang Onjur.

\section{KESIMPULAN}

Berdasarkan hasil analisis mengenai tipologi ketertinggalan wilayah di Kabuapten Sampang, diperoleh beberapa kesimpulan terkait karakteristik wilayah tertinggal dan pengaruh aksesibilitas terhadap pola ketertinggalan wilayah. Kesimpulan-kesimpulan tersebut antara lain:

1. Berdasarkan indikator sumberdaya manusia, ekonomi dan infrastruktur, terdapat tiga kategori ketertinggalan wilayah di Kabupaten Sampang. Ketertinggalan wilayah tinggi mencakup 75 desa, ketertinggalan sedang mencakup 104 desa, dan hanya 7 desa termasuk ke dalam kategori ketertinggalan rendah. Artinya, sebagian besar wilayah di Kabupaten Sampang masih menunjukkan ketertinggalan secara ekonomi, sosial maupun fisik infrastruktur.

2. Aksesibilitas wilayah di Kabupaten Sampang berkorelasi signifikan terhadap tipologi ketertinggalan wilayah. Aksesibilitas yang dimaksud diukur dari jarak desa menuju pusat kecamatan, panjang jalan per luas desa, serta waktu tempuh menuju pusat kecamatan.

3. Jarak desa menuju pusat kecamatan memiliki pengaruh paling tinggi terhadap tipologi ketertinggalan wilayah di Kabupaten Sampang. Sebagian besar wilayah desa memiliki jarak tempuh lebih besar dari $2 \mathrm{Km}$.

4. Ukuran aksesibilitas dengan pengaruh tertinggi kedua adalah panjang jalan per luas desa. Hampir sebagian besar desa di Kabupaten Sampang memiliki panjang jalan per luas wilayah desa yang rendah. Artinya aksesibilitas wilayah desa sebagian besar termasuk kategori rendah.

5. Waktu tempuh menuju pusat kecamatan di Kabupaten Sampang menunjukkan hampir sebagian besar desa memiliki waktu tempuh lebih besar dari 0,5 jam. Artinya, aksesibilitas menuju pusat kecamatan rendah dan wilayah desa semakin tertinggal.

6. Rekomendasi pengembangan kebijakan perbaikan aksesibilitas wilayah desa di Kabupaten Sampang menjadi hal penting bagi pengentasan ketertinggalan wilayahnya. 


\section{DAFTAR PUSTAKA}

[1] Badan Pusat Statistik Kabupaten Sampang. Kabupaten Sampang Dalam Angka 2016, 2016

[2] Amstrong, W and McGee, T.G. Theaters of Accumulation. London. Methuen. 1985

[3] Sejati, M.A dan Muta'ali, L, "Analisis Faktor-faktor Ketertinggalan Wilayah di Kabupaten Sumbawa Barat". 2019. Jurnal Bumi Indonesia, Vol.8, No.3

[4] Muta'ali, Lutfi. Pengembangan wilayah tertinggal. Badan Penerbit Fakultas Geografi (BPFG), 2014

[5] Rustiadi, Ernan. Perencanaan dan pengembangan wilayah. Yayasan Pustaka Obor Indonesia, 2018

[6] Adisasmita, Sakti Adji. Transportasi dan pengembangan wilayah. Graha Ilmu, 2011

[7] Santoso, Singgih. Statistik multivariat: konsep dan aplikasi dengan SPSS. PT Elex Media Koputindo, 2010

[8] Ananth, Cande V., and David G. Kleinbaum. "Regression models for ordinal responses: a review of methods and applications." International journal of epidemiology 26, no. 6 (1997): 1323-1333. 